\title{
GENERAL NO'TES
}

\section{OLD ILLUSTRATION BLOCKS}

IT is our custom to destroy blocks after three years. It may be that some authors would like to have their blocks for possible future use. In such case would they write Headley Brothers, Ashford, Kent, as soon as possible, and in any case within three years of their first being used.

\section{SIXTH INTERNATIONAL CONGRESS OF OTOLARYNGOLOGY}

THE Sixth International Congress of Otolaryngology will be held in Washington, D.C., U.S.A., from May 5th-Ioth, I957. The Secretary-General is Dr. Paul H. Holinger, 7oo N. Michigan Avenue, Chicago Ir, Ill., U.S.A.

\section{NORTH OF ENGLAND OTOLARYNGOLOGICAL SOCIETY}

THE North of England Otolaryngological Society is offering a prize of fifty guineas for original work in Otolaryngology. Candidates must be of Registrar, Senior Registrar or Clinical Assistant status or must have been holding such a post whilst the investigation was in progress. The work must have been carried out in the North of England and the Paper must be submitted by July Ist, I955, to the Hon. Sec., North of England Otolaryngological Society, 28 St. John Street, Manchester 3.

\section{THE ROYAL SOCIETY OF MEDICINE}

THE programmes of the March, I955, meetings of the Sections of Otology and Laryngology are expected to be as follows:

Section of Otology, meeting on Friday, March 4 th, I955, at I0.30 a.m. Discussion: "Mastoid Radiology." Openers: Dr. S. Welin of Malmö and Mr. W. Daggett. The subsequent discussion will be opened by Mr. I. Simson Hall.

Section of Laryngology, meeting on Friday, March 4th, 1955, at 2.30 p.m. Discussion: "The Treatment of Bilateral Abductor Palsy." Openers: Mr. H. P. Lawson and Mr. Neville Young. Paper: Mrs. Florence Cavanagh: "The Occurrence of Vocal Palsies in Infancy." 


\section{General Notes}

\section{OTOLARYNGOLOGY LECTURES I954-55 ROYAL COLLEGE OF SURGEONS}

THE following lectures, arranged jointly by the Royal College of Surgeons of England and the Institute of Laryngology and Otology, will be delivered in the Lecture Hall of the College, at 5.30 p.m.

1955. March 3rd. Mr. A. J. Gardham. The evolution of major surgery in the mouth and pharynx from the time of Trotter to the present day.

March 3ist. Professor Lambert Rogers. Vascular diseases in relation to otolaryngology.

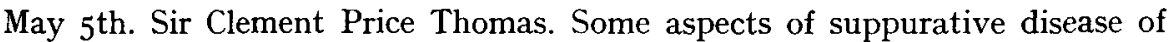
the lungs.

June 3oth. Dr. Thomas Anwyl Davies. The relationship of syphilis to otolaryngology.

\section{ROYAL COLLEGE OF SURGEONS OF ENGLAND}

ThE Court of Examiners reports to the Council that at the recent Final Examination for the Fellowship; I 7 candidates presented themselves for the Examination in Otolaryngology, 6 of whom acquitted themselves satisfactorily.

The following are the names of the 6 candidates who are, therefore, entitled, subject to the approval of the Council, to the Diploma of Fellow:

\begin{tabular}{|c|c|c|}
\hline Name. & Qualification. & Address. \\
\hline $\begin{array}{l}\text { Dixon, James } \\
\text { Theodore }\end{array}$ & $\begin{array}{l}\text { L.R.C.P., M.R.C.S., M.B., } \\
\text { B.S., London., Univ. } \\
\text { Coll. }\end{array}$ & Radcliffe Infirmary, Oxford. \\
\hline Timmis, Peter & $\begin{array}{l}\text { L.R.C.P., M.R.C.S., M.B., } \\
\text { B.S., London, St. Bart's. }\end{array}$ & $\begin{array}{l}\text { Holly Lodge, Roundwood Lane, } \\
\text { Harpenden, Herts. }\end{array}$ \\
\hline Juby, Herbert Bernard & $\begin{array}{l}\text { L.R.C.P., M.R.C.S., M.B., } \\
\text { B.S., London, St. Bart's. }\end{array}$ & $\begin{array}{l}\text { 2a Margaret Road, Costessey, } \\
\text { Norwich. }\end{array}$ \\
\hline Smith, Charles William & $\begin{array}{l}\text { L.R.C.P., M.R.C.S., M.B., } \\
\text { B.S., London, } \\
\text { Thomas's }\end{array}$ & $\begin{array}{l}56 \text { Carlton Avenue, Kenton, } \\
\text { Middlesex. }\end{array}$ \\
\hline eley, Alwyr & $\begin{array}{l}\text { M.B., Ch.B., New Zealand, } \\
\text { I950, Otago. }\end{array}$ & $\begin{array}{r}\text { Flat } 28 \text { Highs } \\
8{ }_{4} \text { Camden } \mathrm{Ro}\end{array}$ \\
\hline onkin, John & $\begin{array}{l}\text { M.B., B.S., Sydney, I950, } \\
\text { Sydney. }\end{array}$ & $\begin{array}{l}\text { London House, Guilford Street, } \\
\text { W.C.I. }\end{array}$ \\
\hline
\end{tabular}

THE attention of members is drawn to the EXCERPTA MEDICA Section XI which is a most valuable international abstracting service as it gives each month abstracts of all the important papers in Oto-Rhino-Laryngology. The subscription is five dollars a year or the equivalent and the agents for Great Britain and the British Empire /excluding Canada and South Africa/are E. and S. Livingstone, Ltd., I6 and 77 Teviot Place, Edinburgh. 


\title{
General Notes
}

\section{THE INSTITUTE OF LARYNGOLOGY AND OTOLOGY}

\author{
Gray's INN RoAD, LONDON, W.C.I
}

\section{SPECIAL LECTURES}

THE Academic Board announces the following special lectures to be given in the Lecture Hall of the Institute at Gray's Inn Road. They are open to all members of the Specialty and to postgraduate students.

Wednesday, March 2nd, at 6 p.m., Dr. H. Engström (Stockholm). "Electron Microscopic examination of the cochlea."

Saturday, March 5th, at I2 noon. Dr. Engström. "Electron microscopic examination of the vestibule."

\section{DATES OF COURSES, I954 and I955}

Fuld Comprehensive Course, suitable for D.L.O. students. August 3 oth, I954, to June Ioth, I955.

Fuli Comprehensive Course, for D.L.O. Students:

(a) Basic Science Class (Part I, D.L.O.), February 21st to May 27 th, 1955.

(b) Intensive Clinical Lecture Course (Part II, D.L.O.), January 3Ist to February $25^{\text {th, }}$ I955.

(c) Complete Clinical Course (Part II, D.L.O.), January 3rd to June Ioth, I955.

Aural Surgery. Course in Practical Aural Surgery, January 21st, 22nd, 23rd, I955.

Advanced Revision Class, for Final F.R.C.S. students, February 7 th to April 22nd, I955.

\section{CANADIAN OTOLARYNGOLOGICAL SOCIETY SOCIÉTÉ CANADIENNE D'OTOLARYNGOLOGIE}

President: Dr. G. Edward Tremble, I390 Sherbrooke St. West, Montreal P.Q. Secretary: Dr. G. Arnold Henry, I70 St. George St., Toronto, Ontario.

Meeting: Bigwin Inn, Lake of Bays, Muskoka, Ontario. June I6th, I7th, I8th, I955.

Mr. R. Scott Stevenson, late of London and now living in Gibraltar, has been invited by the University of Bristol to give the Watson-Williams Memorial Lecture for I954-55; the lecture will be given at the University on Tuesday, March 8th, at 8.30 p.m., on "The New Outlook in Otolaryngology". This Lectureship was established in 1939 with the proceeds of a legacy from the late Dr. Patrick Watson-Williams of Bristol, and is given every third year. 


\title{
POST-TONSILLECTOMY COMFORT
}

\section{Immediate pain relief-Speedier Convalescence}

The pain of traumatized tissues following tonsillectomy, demands its own relief - and points the need for analgesia that quickly reaches the irritated area.

ASPERGUM provides 'salivary analgesia' through the simple act of chewing - it brings pain-relieving acetylsalicylic acid into intimate and prolonged confacl with the tonsiliar region, seldom reached even intermittently by gargling. The rhythmic stimulation of muscular action also aids in relieving local spasticity \& stiffness : more rapid tissue repair is promoted Each pleasantly flavoured chewing gum tablet provides $3 \mathrm{i}$ grains acetylsalicylic acid, permitting frequent use. Particularly suitable for children.

\section{Aspergum}

for more than two decades a dependable and welcome aid to patient-comfort

Ethically promoted. Prescription bottles of 36 tablets, dispensing bottles of 250 .

WHITE LABORATORIES LTD., 428, SOUTHCROFT ROAD, LONDON, S.W.16

\section{THE LARYNGOSCOPE}

\author{
A Monthly Journal
}

devoted to the Diseases of the

EAR, NOSE AND THROAT

Official organ for the American Laryngological, Rhinological and Otological Society

Price $\$ 14.00$ per year

MAX A. GOLDSTEIN, M.D. FOUNDER
Canada $\$ 13.00$ per year

THEODORE E. WALSH, M.D. EDITOR

\section{SOUTH KINGSHIGHWAY SAINT LOUIS 10, MO.}


ELECTRIC I954 model designed for use in explosion prone atmosphere.

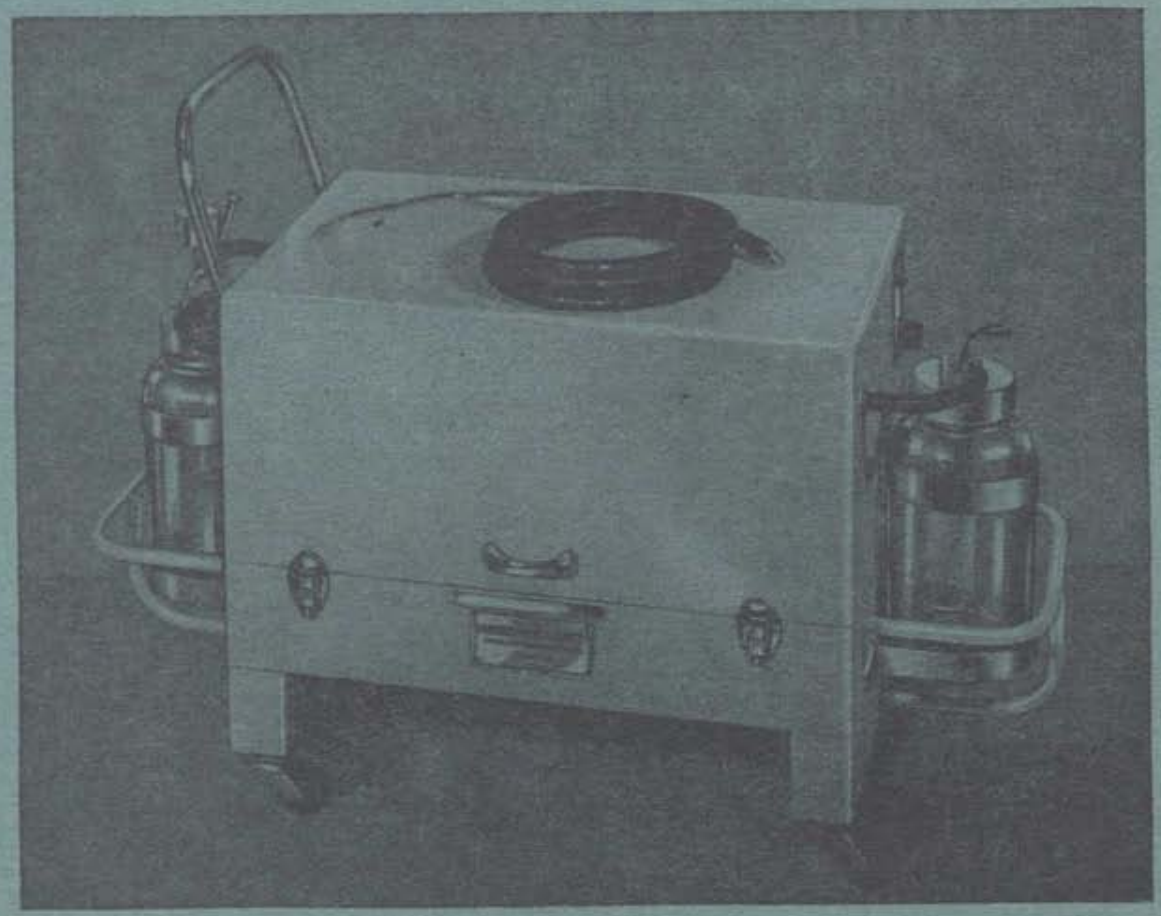

Foot Model, in case of electric supply failure.

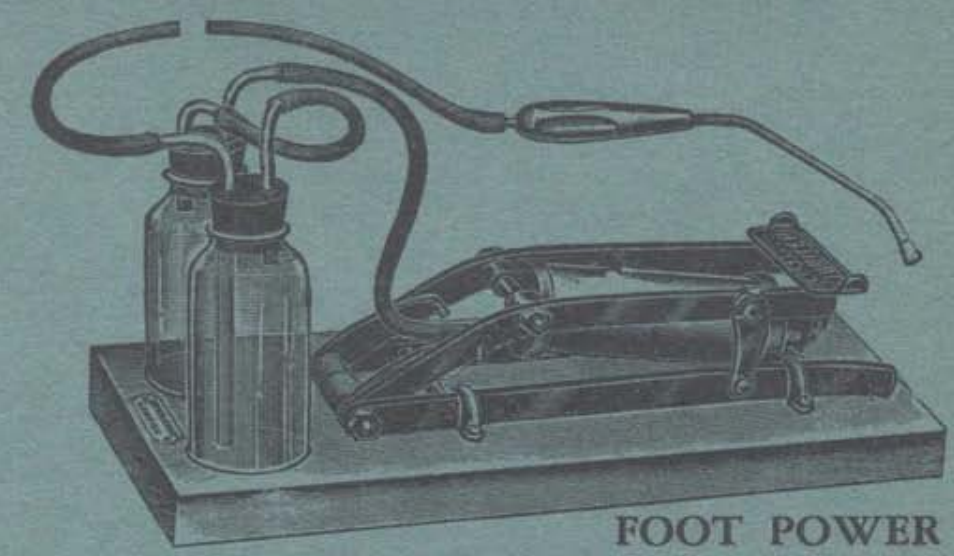

\section{SUCTION APPARATUS}

Particulars on application

\section{DOWN BROS. \& MAYER \& PHELPS Ltd.}

Head Office: 92-94 Borough High Street, London, S.E.1 HOP: 4141 Showrooms: 32-34 New Cavendish Street, London, W.1 WEL: 3764 